\title{
Study on Promoting English Autonomous Learning of College Students through M-learning
}

\author{
Changzhen Ju
}

Wuhan Donghu University, Wuhan, Hubei

Keywords: M-learning; college students; autonomous learning

\begin{abstract}
With the widespread use of smart phones, M-learning is becoming a new trend. And college English teaching should make full use of M-learning to develop students' learning autonomy. This paper discusses the feasibility of M-learning and how to promote college students' English autonomous learning through M-learning outside the classroom.
\end{abstract}

\section{Introduction}

In the era of knowledge explosion, the idea of life-long learning and life-wide learning have been accepted as a fact. And to achieve life-long learning and life-wide learning, autonomous learning is a suitable approach which has been a hot topic. Holec's (1981) defines autonomy as 'the ability to take charge of one's own learning which has proved remarkably robust and remains the most widely cited definition in the field. This ability, in fact, usually accompany a person in his whole life and decides what a person can achieve in his whole life because we are living in an age of knowledge explosion in which we cannot learn all the knowledge we need at one time on campus. Therefore, what a university should do is to cultivate students' autonomous learning ability so that in the future when they graduate from the university they can much more easily learn the knowledge they need by their own. In fact, the development of the internet and the popularity of mobile terminals has greatly promote a person's autonomous learning. Therefore, dating back to 2000, Desmond Keegan (2000), an Irish expert on distance education, believed that the function of voice input would be added to mobile communication terminals, and this would greatly help M-learning (mobile learning) and make M-learning more convenient, which has become a fact.

More and more university students are using their social networking services and even some of them are addicted to their mobile phones. Therefore, how to guide university students to use their mobile phones properly is what we should consider. One of the ways to guide students is to promote their mobile learning, which will not only cultivate their autonomous learning ability but also make their use of mobile phone more meaningful instead of wasting their time. This paper focuses on how to promote university students’ autonomous learning ability through M-learning.

\section{Literature Review}

An autonomy-supportive environment for learners to engage in activities that allow them to develop a capacity to control their learning can be created both inside and outside the classroom (Benson 2001). Self-access is an approach to learning language which has been widely recognized as an approach to promoting autonomy as it encourages learners to move from being teacher-dependent to autonomous (Gardner \& Miller 1999; Sheerin 1991, 1997). It can take place either in self-access centers or be incorporated into language programs. The researches at home and abroad show that self-access centers provide non-English majors with great convenience for promoting their autonomy. Jiang (2012) compare the self-access centers at home and abroad, and analyze the composition of application of them, and make some suggestions to use self-access centers and promote the development of autonomy. Cai (2008) points out that teachers play an important role in the process of promoting students' autonomy by using self-access centers, and teachers should be always enthusiastic about developing students' autonomy and should attend more training. 
The trajectory of autonomy in language education up to the end of the 20th century was characterized by an early focus on self-directed learning in self-access centres, followed in the 1990s by a shift toward classroom applications. (Phil Benson,2011) The most significant development in the field of classroom autonomy, however, is marked by the appearance of several general books on language teaching and learning with sections on autonomy, including Hedge (2000), Harmer (2001) and Kumaravadivelu (2003) on teaching methodology, Nation (2001) on vocabulary and Thornbury (2005) on speaking.

Recent studies suggest that students tend to engage in out-of-class learning activities more frequently than their teachers know. The term 'out-of-class learning' has been used, somewhat narrowly, to refer to the efforts of learners taking classroom-based language courses to find opportunities for language learning and use outside class (Hyland 2004). Whether learning beyond classroom can foster the development of students' autonomy is still a question which need more research. But domestic and international scholars think it necessary to train language learners about meta-cognitive knowledge and learning strategies. Song (2002) suggest that teachers should help students set up learning belief and interest, guide students to reflect and accumulate their learning strategy in order to improve their ability of autonomous learning. Zhang (2004) use two modes "Meta-cognitive Strategy Training in Class" and "Signing Learner Contract with the Learner after Class” to develop learner autonomy. He finds that the learners' autonomous awareness has greatly improved, and that learners have employed meta-cognitive strategies more frequently and the method of signing learner contract with the learners not only developed learners' autonomous learning habit, but also improve learners' listening, reading and writing abilities, and that development of learner autonomy is helpful in improving learners' learning achievement. He (2003) points out that to foster students' learning autonomy teachers should stimulate students' interest, help and guide students to develop sustainable learning motivation and organize students to form cooperative learning groups

More and more mobile devices are used in English teaching and learning, laptop, pad, mobile phones, etc. The most frequently used device in students' out-of-class learning is mobile phone, because it's easy to carry and convenient to use, and students can use them wherever and whenever. So researchers begin to think how to transfer from CALL to MALL, and focus on how to guide students' M-learning to foster their autonomy. Wang (2014) designs a teaching module of the information management and information system based on M-leaning. Liu and Zhu (2016) provide some online teaching resources and learning resources and some apps according to four language learning skills, writing, speaking, listening and translating, and hope teachers can blend classroom learning with out-of-class learning to promote students' learning autonomy.

\section{M-learning}

The mobile network has covered all the round China and the high speed of rate of accessing to internet on the mobile terminals and the reduction of telecommunication fees provide good conditions for massive use of M-learning.

According to a report on April 26, 2017, the number of using 4G network in China had reached 836 million, which accounts more than half of the whole population in China. And except access to mobile network, much more areas are covered with free $\mathrm{WiFi}$, which makes it more easier to access to internet. And the bills of telecommunication is reducing. Besides almost all the college students are using smart phones which can access to internet easily. Liu and Lu (2014) makes an investigation in an university, and they find that there are good chances that smart phones are introduced into the classroom and become a useful device in the era of M-learning. Therefore, we could guide our students to make more good use of their smart phone, that is, to guide them to learn what they need on the smart phone.

In recent years, the classroom learning periods of English are reduced in many universities while the requirements of college students' language ability are not lowered. Therefore, college English teachers must run their brain to find more opportunities for students to practice what they have learned in classroom and find more opportunities to extend their learning periods outside the 
classroom.

Some scholars have made some good attempts. For example, Meng and Chen (2014) discusses the feasibility of application of WeChat Public Platform in the mobile teaching, puts forward a complete construction plan that based upon the existing network teaching system in colleges and universities and the mobile learning space of WeChat Public Platform, and researches the functional design of learning space and realization line of critical technology. Dou and Wen (2015) analyze the difficulties of college English teaching in the era of M-learning and suggest a flipped classroom teaching mode based the use of App.

These researches are great attempts in M-learning. Not only the hard ware but also the learning and teaching environment suggest that M-learning should be much more used in college English teaching to promote students' autonomy.

M-learning have several characteristics. They are as follows.

First, M-learning expands the learning space. Learners can learn on their smart phones or PAD anywhere outside the classroom, on the bus, on the subway, at the rail station or at the airport, anywhere they have free time.

Second, M-learning is instantaneous. When learners meet difficulties in learning or life, they can find solution immediately on the smart phone or ask someone through QQ or Wechat.

Third, M-learning is individual. Every learners can download different Apps according to his own needs, to find what he likes or what is suitable for him.

Fourth, learning on the mobiles devices really lighten learners' backpacks. Learners can put massive learning resources on their mobile devices without taking a heavy backpack. This is an important reason why nowadays young learners tend to learn on the internet.

\section{Promoting Students' Language Learning Autonomy through M-learning}

The literature review and the discussion about the necessity and feasibility show that it's possible to promote students' language learning autonomy through M-learning. Then comes the question of how to promote students' learning autonomy, this paper discusses the question from three different aspects and hopes it will give some inspiration to the solution to this question.

Although M-learning provide students with great convenience, it is better to be guided by teachers and combined with classroom learning. In this way, the autonomous learning outside the classroom can be more goal-oriented and more systematic. Teachers should set language learning goals and work for students and direct and monitor students' learning process for autonomous learning.

It is a good attempt to use Wechat groups as a tool to monitor students. First, group work is a favorite means for students. In this imagined community, students can discuss questions and make mutual supervision. They can also learn collaboration and exercise their initiatives. Second, in order to stimulate students to participate in the activities in the Wechat group, teachers can set different stimulant strategies. For example, those who take part in the activities for three minutes can have a chance to share an interesting topic or movie in the classroom, or those who take part in the activities for ten times have a chance to get a personal face-to-face talk with a foreign teacher in the English department.

Since the classroom learning periods are limited, teachers should take full advantages of the out-of-class learning to help students expand the related topic they learned in the classroom or deepen the topic discussion they have discussed in the classroom. Therefore, tasks assigned outside the classroom for autonomous learning should have the following characteristics. First, the tasks should have a goal and it's better to have goal which is related to the teaching goal in the classroom. This corresponds to the theory of zone of proximal development and it's easy to do. Second, it should be stratified so that different students at different levels can achieve different goals through autonomous learning. Third, those tasks should be interesting and the materials that is given should be authentic so that students' interest can be stimulated and they feel it's useful to learn.

The scientific, objective and instant assessment of students' learning can greatly stimulate students' interest and motivation to keep on learning. First, teachers should inform students of the 
assessment rules beforehand so that students know that teachers regard their autonomous learning seriously. Second, the assessment system can include three parts: teachers' assessment, partners' assessment and personal assessment. In this way, students can have a better understanding of what he did and how he did it. Third, the objects of being assessed should include students' autonomous learning work and their discussion among them and the participation in the discussion and the collaboration between each other.

\section{Conclusion}

M-learning has been a modern trend, which happens everyday and everywhere. Teachers are trying hard to transfer their roles to take advantage of M-learning to develop students' autonomous learning. This paper reviews the researches on M-learning and autonomous learning, and give some suggestions about guiding students to practice autonomous learning outside the classroom. It hopes that more and more teachers try the empirical approach to combine the classroom learning with the out-of-classroom learning and promote students' autonomy.

\section{References}

[1] Gardner, D., Miller, L. (1999). Establishing self-access: From theory to practice. Cambridge: Cambridge University Press.

[2] Harmer, J. (2001). The practice of English language teaching. ( ${ }^{\text {rd }}$ ed.). London: Pearson Education.

[3] Hedge, T. (2000). Teaching and learning in the language classroom. Oxford: Oxford University Press.

[4] Holec, H. (1981). Autonomy in foreign language learning (first published 1979, Strasbourg: Council of Europe). Oxford: Pergamon.

[5] Hyland, F. (2004). Learning autonomously: Contextualising out-of-class English language learning. Language Awareness 13.3, 180-202.

[6] Kumaravadivelu, B. (2003). Beyond methods: Macrostrategies for language teaching. New Haven: Yale University Press.

[7] Nation, I. S. P. (2001). Teaching and learning vocabulary in another language. Cambridge: Cambridge University Press.

[8] Phil Benson Autonomy in language teaching and learning Hong Kong Institute of Education http://journals.cambridge.org Downloaded: 22 Dec. 2017

[9] Sheerin, S. (1991). Self-access: State-of-the-art-article. Language Teaching, 24 (3),143-157.

[10] Sherrin, S. (1997). An exploration of the relationship between self-access and independent learning. In P. Benson, \& P. Voller (Eds.), Autonomy \& independence in language learning. London: Longman.

[11] Thornbury, S. (2005). How to teach speaking. London: Longman.

[12] Cai Chaohui. 2008. The Role of Teachers in English Self-access Learning of College StudentsA Contrastive Study between UNCC and Three Tertiary Schools [J]. Foreign Languages and Their Teaching (11).

[13] Dou Juhua, Wen Shan. 2015. The Teaching Reform Exploration of College English Flipped Classroom Based on APP [J]. Heilongjiang Researches on Higher Education, (5).

[14] He Lianzhen. 2003. The Cultivation of Self-learning and Its Capability [J]. Foreign Language Teaching and Research (4).

[15] Jiang Juan. 2012. The Realization of College English Self-learning with Self-access Centre [J]. 
Journal of Southwest Agricultural University (Social Science Edition), (12).

[16] Liu Shixiang, Zhu Bingyan. 2016. APP-enhanced EFL Blended Teaching in the Context of M-learning-Taking Android for an Example [J]. Journal of Minxi Vocational and Technical College (3).

[17] Liu Yonghui, Lu Lijin. 2014. Possibility of Inputting Mobile Phone into the College English Learning [J]. Journal of Central South University of Forestry\& Technology (Social Science), (1).

[18] Meng Fanli, Chen Lin. 2014. Research on the Construction of Mobile Learning Space Based on WeChat Public Platform [J]. Modern Educational Technology (10).

[19] Song Lili. 2002. A New English Teaching Approach for Promoting Autonomous Learning-A Report on the Teaching of an Experimental Class [J]. Research on Education Tsinghua University (S1).

[20] Wang Lili. 2014. Research on Teaching Model Based on the M-learning [J]. Journal of Dezhou University (1).

[21] Zhang Yanjun. 2004. Experiment on the Cultivation of Learner Autonomy with Learner Training [J]. Foreign Language World (1).

[22] http://finance.sina.com.cn/roll/2017-04-26/doc-ifyetstt3452255.shtml 